\title{
Effects of Variety and Nitrogen Levels on the Performance of Pearl Millet: Pennisetum Glaucum (L.) R. BR.
}

\author{
S. Isah ${ }^{1}$, A. U. Gbanguba ${ }^{2 *}$, Y. Abdullah ${ }^{2}$, T. S. Bubuche ${ }^{2}$, T. Mohammed $^{3}$ \\ ${ }^{1}$ Department of Crop Production Technology, Niger State College of Agriculture, PMB 109 Mokwa, Nigeria. \\ ${ }^{2}$ National Cereals Research Institute, Badeggi, PMB 8 Bida, Niger State, Nigeria. \\ ${ }^{2}$ Crop Science Department, Kebbi State University of Science and Technology, Aliero, Nigeria.
}

Received 03 October 2020; Revised 16 November 2020; Accepted 23 November 2020; Published 01 December 2020

\begin{abstract}
The trials were conducted in the 2010 and 2011 rainy seasons at Usmanu Danfodiyo University, Sokoto Teaching and Research Dry Land Farm, Dundaye, Nigeria to determine the effects of variety and nitrogen levels on the performance of SOSAT c-88 and Zango millet varieties. Data on stand count, tiller count, plant height, and panicle length were collected. Others included panicle weight and grain yield. An analysis of variance (ANOVA) was performed on all collected data. The results of SOSAT $c-88$ and Zango millet indicated that millet varieties have no significant effect on both stand and tiller production throughout the sampling periods, though nitrogen levels have a significant effect on tiller production at 6 weeks after planting in both the 2010 and 2011 cropping seasons. Panicle length was affected by millet varieties and nitrogen levels in both cropping seasons. Improve millet variety Sosat c- 88 gave higher grain yield while $80 \mathrm{~kg} \mathrm{ha}^{-1}$ and $120 \mathrm{~kg} \mathrm{ha}^{-1}$ produced significant higher millet grain yield hence should be practiced.

Keywords: Variety; Nitrogen Levels; Performance; Pearl Millet.
\end{abstract}

\section{Introduction}

Pearl millet "Pennisetum glaucum (L.)" belongs to the family Poaceae, subfamily Panicoideae, genus Pennisetum and tribe Panaceae (ICRISAT, 2006) [1-3]. In those situations where other crops generally fail, it is largely grown for grain and fodder purposes. Pearl millet as a food crop is limited to the developing countries in Asia, and particularly in Africa, where it is ranked sixth in the world following rice, wheat, corn, barley, and sorghum [4]. Millet ranks as the sixth most important grain crop in the world, sustains one-third of the world population, and is a significant part of the diet in Northern China, Japan, Manchuria, and various areas of the former Soviet Union, Africa, India, and Egypt [5]. It is one of the most important cereal crops grown in over 40 countries, predominantly in Africa and Asia, as a staple food, source of feed, fodder, fuel and construction material in the hottest, driest, semi-arid and areas where rain-fed agriculture is practiced [1].

The average grain yield of millet in Nigeria is about $1.55 \mathrm{tha}^{-1}$ (FAOSTAT, 2006), which is considered very low compared to the global yield of $3.2 \mathrm{t} \mathrm{ha}^{-1}$ [5]. The reasons attributed to this low yield include biotic and abiotic constraints; limited research on development; unfavorable agricultural policies; and lack of trained manpower [6]. The

\footnotetext{
* Corresponding author: augbanguba@gmail.com

doi) http://dx.doi.org/10. 28991/HEF-2020-01-04-04

$>$ This is an open access article under the CC-BY license (https://creativecommons.org/licenses/by/4.0/).

(C) Authors retain all copyrights.
} 
nutrient content of pearl millet compares very well with other cereals and millets. It has a high protein content with a slightly superior amino acid profile. Pearl millet grain contains 13-14 percent protein, 5-6 percent fat, 74 percent carbohydrate and 1-2 percent minerals. It also contains a higher amount of carotene, riboflavin (Vitamin $\mathrm{B}_{2}$ ), and niacin (Vitamin $\mathrm{B}_{4}$ ) [7]. According to Gruhn et al. (2000) [8], insufficient application of nutrients and poor soil management, along with harsh climatic conditions and other factors, have contributed to the degradation of soils in sub-saharan Africa, which causes plants to fall over and die before harvest.

Suitable fertilizer programs are essential to achieve optimum grain production. Until 1982, very little information was available on the fertilizer requirements of pearl millet for the savanna region [9]. Use of manure is constrained by its inadequate supply, which could be too little to meet the farmers' requirements for all their cropped land; in addition, manure is bulky to handle [10]. Soils in the savanna region of Nigeria are low in nutrient and organic matter content. Soil degradation has increased and has become a serious threat to agricultural production [11]. Continuous and intensive crop cultivation with near absence of fallow period long enough for restoring soil fertility and low use of external source of inputs are common practice among many small scale farmers in Nigeria [11, 12]. Maintenance of soil fertility on farm lands has become very difficult as many of them have limited access to fertilizer (inorganic fertilizer) due to government withdrawal of subsidies on the input, which has led to its high cost and unavailability [13].

The soils in this region have shown a continuous decline in fertility and productivity with an attendant poor yield of grain crops when fertilizers are not applied [11]. Soils in the tropics are very low in N, P, and K content, and N is the most limiting factor for cereal production [14]. The major reasons for declining soil fertility are the need to crop the land more intensively due to an increased human population and low application of inorganic fertilizers and manures; therefore, nutrients extracted by crops are not adequately replaced in the soil [5]. Appropriate selection of a good variety is one of the prerequisites to successful crop production in relation to vigour, growth, and yield. Good variety may have highly likely to be better efficiency in utilizing both above and below ground resources, thereby enhancing its potential economic yield, and in the case of bad variety, the reverse is the case. Millet varieties are classified based on the shape of the panicle, which includes spreading, loose and compact, and erect. Early maturing millet seed contains only small food reserves, fewer leaves, fibrous root systems, the lateral roots are strong and penetrate the soil down to $200 \mathrm{~cm}$, and the aerial roots are well developed [15]. FAO and ICRISAT (1996) [16] reported that the largest variability in maturity period, head size and shape, and grain size is found in West Africa, the main centre of origin. Among the land races, the Sauna (early, 70 to 90 days) and Sanio (late, 120 to 180 days) are the most common.

\section{Materials And Methods}

The trials were conducted in 2010 and 2011 rainy seasons at Usmanu Danfodiyo University, Sokoto Teaching and Research Dry Land Farm, Dundaye located on latitude $13^{\circ} 01^{1} \mathrm{~N}$; longitude $5^{\circ} 15^{1} \mathrm{E}$ and at an altitude of about $350 \mathrm{~m}$ above sea level in the Sudan savanna agro-ecological zone of Nigeria [17].

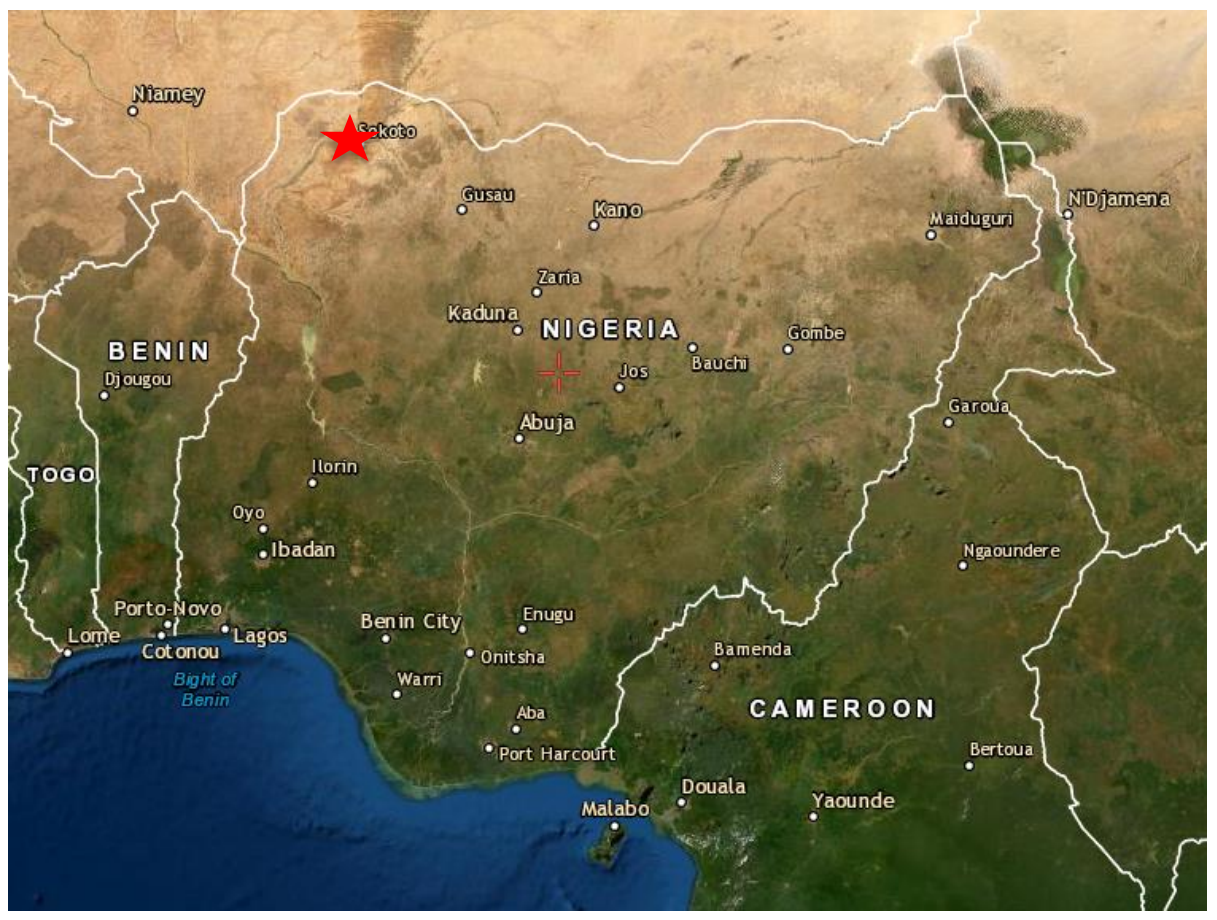

Figure 1. Location of Sokoto State in Nigeria 
The annual rainfall of the area during the period of trials were 1,157.4 $\mathrm{mm}$ and $558.4 \mathrm{~mm}$, respectively [18]. The soil type of the area is predominantly sandy and has been classified as Ustipsamment [19]. Two varieties of millet, improved (SOSAT C-88) and local (Zango), four levels of Nitrogen (0, 40, 80 and $120 \mathrm{~kg} / \mathrm{ha}$ ) were factorially combined and laid out in a randomized complete block design (RCBD) replicated three times. Data collected were stand count, tiller count, plant height and panicle length. Other data taken include panicle weight Stover and grain yield. Data collected were subjected to analysis of variance (ANOVA) procedure for randomized complete block design (RCBD) using statistical analysis system (SAS 2003) [20]. Duncan's Multiple Range Test (DMRT) was used to separate treatment means where ' $\mathrm{F}$ ' test shows significant difference between the treatments as described by Gomez \& Gomez (1984) [21].

\section{Results and Discussion}

\subsection{Stand Count}

There was no significant difference among the two varieties SOSAT c-88 and Zango millet in terms of stand count in both 2010 and 2011 cropping seasons (Table 1) The varieties were statistically the same in terms of stand count (P > 0.05) 112345, 111851, and 12592, 111974 was obtained in SOSAT C-88 and Zango Millet variety in 2010 and 2011 respectfully. This is in conformity with what was reported by Egharevba et al. (1984) [22] that in cereals (millet and sorghum) stand count hardly affected significantly by variety if both environment and soil condition are favorable. Significant effect $(\mathrm{P}<0.05)$ of Nitrogen fertilizer application was found on millet variety stand count in 2011 rainy season when $40 \mathrm{~kg} / \mathrm{ha}$ Nitrogen was applied. Stand count in both cropping seasons was not significantly affected by interaction between variety and nitrogen fertilizer application (Table 1).

Table 1. Effect of varieties, nitrogen levels on Stand count during 2010 and 2011 cropping seasons at Usmanu Danfodiyo University Teaching and Research Dry Land Farm, Sokoto

\begin{tabular}{cccc}
\hline Treatments & $\mathbf{2 0 1 0}$ & $\mathbf{2 0 1 1}$ \\
\hline Variety $(\mathbf{V})$ & & 111851 \\
\hline SOSAT C-88 & 112345 & 111974 \\
Zango Millet & 112592 & 301.84 \\
SE \pm & 385.70 & Ns \\
Significance & Ns & $\mathbf{2 0 1 1}$ \\
\hline Nitrogen $(\mathbf{N})$ kgha $^{-1}$ & $\mathbf{2 0 1 0}$ & $111851 \mathrm{~b}$ \\
\hline 0 & 112592 & $112345 \mathrm{a}$ \\
40 & 112592 & $111851 \mathrm{~b}$ \\
80 & 112098 & $111604 \mathrm{~b}$ \\
SE \pm & 112592 & 426.87 \\
Significance & 545.46 & $*$ \\
\hline Interaction & Ns & Ns \\
\hline
\end{tabular}

Means in a column followed by similar letter (s) are not significantly different at $5 \%$ level of significance using Duncan's Multiple Range Test (DMRT) ns= not significant, * = significant at 5\% level.

\subsection{Tiller Count}

Tiller count of millet at 3WAS and 6WAS as influenced by Variety and Nitrogen levels in 2010 and 2011 cropping seasons are presented in (Table 2). There was no significant difference ( $>>0.05)$ between the varieties on their tiller count at 3WAS and 6WAS in both 2010 and 2011 cropping seasons. This is in line with what was reported by Egharevba et al. (1984) [22] that cereals (millet and sorghum) tiller counts hardly affected significantly by variety if both environment and soil condition are favourable. Results showed no significant effect of nitrogen levels on tiller count at 3 WAS in both 2010 and 2011 seasons. Conversely, tiller count at 6 WAS recorded significant effect of nitrogen fertilizer application in both seasons. All the levels of nitrogen were the same $(\mathrm{P}>0.05)$ and differed only from the control. This could be due to split application of fertilizer (nitrogen) at 4 WAS that recorded significantly higher tiller count than the application of nitrogen at 2 WAS and it may probably be that tillering initiation started later after application of first dose of nitrogen fertilizer ( 2 WAS). This is in line with the findings by Pandey \& Sinha (2010) [23] that the application of nitrogen fertilizer at right time (Split) and at higher level enhances many aspects of plant physiological stages involving photosynthesis, root growth and development, tallness or elongation of structural tissues such as stalk in cereals. There was no interaction effect of variety and nitrogen fertilizer application on tiller number (Table 2). 
Table 2. Effect of varieties, nitrogen levels on Tiller count at 3WAS and 6WAS during 2010 and 2011 cropping seasons at Usmanu Danfodiyo University Teaching and Research Dry Land Farm, Sokoto

\begin{tabular}{ccccc}
\hline \multirow{2}{*}{ Treatments } & \multicolumn{2}{c}{2010} & \multicolumn{2}{c}{ 2011 } \\
\cline { 2 - 5 } & 3WAS & 6WAS & 3WAS & 6WAS \\
\hline Variety (V) & & & & \\
\hline SOSAT C-88 & 3.8 & 12.8 & 3.0 & 11.2 \\
Zango millet & 4.6 & 14.0 & 3.6 & 12.7 \\
SE \pm & 0.3 & 0.7 & 0.3 & 0.6 \\
Significance & Ns & Ns & Ns & Ns \\
\hline Nitrogen (N) kgha $^{-1}$ & & & & \\
\hline 0 & 3.5 & $10.2^{\mathrm{b}}$ & 3 & $9.4^{\mathrm{b}}$ \\
40 & 4.7 & $13.4^{\mathrm{a}}$ & 3.8 & $12.1^{\mathrm{a}}$ \\
80 & 4.3 & $15.8^{\mathrm{a}}$ & 3.2 & $13.4^{\mathrm{a}}$ \\
120 & 4.1 & $14.5^{\mathrm{a}}$ & 3.3 & $12.8^{\mathrm{a}}$ \\
SE \pm & 0.4 & 0.9 & 0.4 & 0.8 \\
Significance & $\mathrm{Ns}$ & $*$ & $\mathrm{Ns}$ & $*$ \\
\hline Interaction & $\mathrm{Ns}$ & $\mathrm{Ns}$ & $\mathrm{Ns}$ & $\mathrm{Ns}$ \\
\hline
\end{tabular}

Means in a column followed by similar letter (s) are not significantly different at $5 \%$ level of significance using Duncan's Multiple Range Test (DMRT) Ns= not significant, * = significant at 5\% level.

\subsection{Plant Height}

Effects of variety, nitrogen levels and their interactions on plant height at maturity in millet are presented in Table 3. The result showed that there was no significant effect ( $p>0.05$ ) on variety on plant height in both 2010 and 2011 cropping seasons. But in comparing their means, Zango Millet recorded significantly taller plant than SOSAT C-88 in both 2010 and 2011 cropping seasons. This result is in line with Raemaekers (2001) [24] who reported that local varieties are taller than the improved varieties. Results showed significant differences as influenced by nitrogen fertilizer application on plant height at maturity in both 2010 and 2011 cropping seasons. Nitrogen fertilizer application rate at $120 \mathrm{kgha}^{-1}$ revealed significantly tallest plants than the remaining nitrogen levels in both cropping seasons (Table 3). This is similar with findings by Pandey \& Sinha (2010) [23], that the application of nitrogen fertilizer at right time (split) and higher level enhances many aspect of plant physiological stages involving photosynthesis, root growth and development, tallness or elongation of structural tissues such as stalk in cereal crops. Regarding to variety and nitrogen fertilizer application interaction, no statistical significant $(\mathrm{P}>0.05)$ effects were observed on plant height at maturity.

Table 3. Effect of varieties, nitrogen levels on Plant height at maturity in 2010 and 2011 cropping seasons at Usmanu Danfodiyo University Teaching and Research Dry Land Farm, Sokoto

\begin{tabular}{cccc}
\hline Treatments & $\mathbf{2 0 1 0}$ & $\mathbf{2 0 1 1}$ \\
\hline Variety $(\mathbf{V})$ & 183.4 & 178.6 \\
SOSAT C-88 & 191.7 & 186.1 \\
Zango Millet & 2.9 & 2.6 \\
SE \pm & $\mathrm{Ns}$ & $\mathrm{Ns}$ \\
\hline Significance & $\mathbf{2 0 1 0}$ & $\mathbf{2 0 1 1}$ \\
\hline Nitrogen $(\mathbf{N}) \mathbf{k g h a}^{-1}$ & $160.3^{\mathrm{d}}$ & $155.7^{\mathrm{d}}$ \\
\hline 0 & $178.6^{\mathrm{c}}$ & $174.0^{\mathrm{c}}$ \\
40 & $197.7^{\mathrm{b}}$ & $192.6^{\mathrm{b}}$ \\
120 & $213.6^{\mathrm{a}}$ & $207.0^{\mathrm{a}}$ \\
SE \pm & 4.1 & 3.7 \\
Significance & $*$ & $*$ \\
\hline Interaction & $\mathrm{Ns}$ & $\mathrm{Ns}$ \\
\hline
\end{tabular}


Means in a column followed by similar letter (s) are not significantly different at $5 \%$ level of significance using Duncan's Multiple Range Test (DMRT) ns= not significant, * = significant at 5\% level

\subsection{Panicle length}

There was significant effect $(\mathrm{P}<0.05$ ) of variety on panicle length in both 2010 and 2011 cropping seasons (Table 4). Zango millet in both trials recorded the longer panicle which was significantly higher than what was recorded in the improved (SOSAT C-88). This finding is in line with Raemaekers (2001) [24] who reported that local varieties are taller than the improved varieties. This also agreed with Jennis (2006) [25], who reported that millet plant vary in panicle length, seed size, seed colour and plant height depending on the cultivars and environment. Nitrogen levels had significant effect on panicle length in both seasons. From $0-40 \mathrm{KgNha}^{-1}$ panicle length increases but at $80-120$ $\mathrm{KgNha}^{-1}$, panicle length increase is at maximum. This is similar with the findings of Pandey and Sinha (2010) [23] that the application of nitrogen fertilizer at right time enhances many aspects of physiological stages involving photosynthesis, root growth and development and elongation of structural tissues such as stalk in cereals.

Table 4. Effect of varieties, nitrogen levels on Panicle length $(\mathrm{cm})$ in 2010 and 2011 cropping seasons at Usmanu Danfodiyo University Teaching and Research Dry Land Farm, Sokoto

\begin{tabular}{ccc}
\hline Treatments & $\mathbf{2 0 1 0}$ & $\mathbf{2 0 1 1}$ \\
\hline Variety (V) & $39.0^{\mathrm{b}}$ & $37.5^{\mathrm{b}}$ \\
\hline SOSAT C-88 & $47.1^{\mathrm{a}}$ & $45.3^{\mathrm{a}}$ \\
Zango Millet & 0.8 & 0.8 \\
SE \pm & $*$ & $*$ \\
Significance & $\mathbf{2 0 1 0}$ & $\mathbf{2 0 1 1}$ \\
\hline Nitrogen (N) kgha ${ }^{-1}$ & $37.6^{\mathrm{c}}$ & $36.1^{\mathrm{c}}$ \\
\hline 0 & $41.8^{\mathrm{b}}$ & $40.1^{\mathrm{b}}$ \\
40 & $46.3^{\mathrm{a}}$ & $44.5^{\mathrm{a}}$ \\
120 & $46.5^{\mathrm{a}}$ & $45.0^{\mathrm{a}}$ \\
SE \pm & 1.1 & 1.1 \\
Significance & $*$ & $*$ \\
\hline Interaction (VXN) & $*$ & $*$ \\
\hline
\end{tabular}

Means in a column followed by similar letter (s) are not significantly different at $5 \%$ level of significance using Duncan's Multiple Range Test (DMRT) ns = not significant, $*=$ significant at 5\% level.

There was interaction effect of variety and nitrogen fertilizer application on panicle length in both 2010 and 2011 cropping seasons as indicated in Table 5. The results revealed that the two varieties of millet showed significant differences of panicle length with levels of nitrogen fertilizer application. With application of 0-40 KgNha ${ }^{-1}$, panicle length increases in both variety but at $80-120 \mathrm{KgNha}^{-1}$, panicle length is at maximum for Zango millet but not in SOSAT C-88 as shown in Table 5. This finding is in line with what was reported by Hassan \& Bibinu (2010) [26] that the interaction effect of Ex-Borno millet variety and $90 \mathrm{kgNha}^{-1}$ gave the highest panicle length than SOSAT- C-88 and LC-IC9702 millet varieties.

Table 5. Interaction effect of varieties, nitrogen levels on Panicle length $(\mathrm{cm})$ during 2010 and $2011 \mathrm{cropping}$ seasons at Usmanu Danfodiyo University Teaching and Research Dry Land Farm, Sokoto

\begin{tabular}{ccccc}
\hline Nitrogen $(\mathbf{N}) \mathbf{k g h a}^{-1}$ & \multicolumn{2}{c}{$\mathbf{2 0 1 0}$ (Variety) } & \multicolumn{2}{c}{$\mathbf{2 0 1 1}$ (Variety) } \\
\hline & SOSAT C-88 & Zango Millet & SOSAT C-88 & Zango Millet \\
\hline $0 \mathrm{kgha}^{-1}$ & $36.8^{\mathrm{c}}$ & $38.5^{\mathrm{c}}$ & $35.7^{\mathrm{c}}$ & $36.6^{\mathrm{c}}$ \\
$40 \mathrm{kgha}^{-1}$ & $39.7^{\mathrm{bc}}$ & $43.8^{\mathrm{b}}$ & $38.2^{\mathrm{bc}}$ & $42.0^{\mathrm{b}}$ \\
$80 \mathrm{kgha}^{-1}$ & $40.8^{\mathrm{bc}}$ & $51.8^{\mathrm{a}}$ & $39.1^{\mathrm{bc}}$ & $49.9^{\mathrm{a}}$ \\
$120 \mathrm{kgha}^{-1}$ & $38.6^{\mathrm{c}}$ & $54.4^{\mathrm{a}}$ & $37.0^{\mathrm{c}}$ & $53.0^{\mathrm{a}}$ \\
$\mathrm{SE} \pm$ & 1.6 & - & 1.5 & - \\
\hline
\end{tabular}


Mean with the same letter(s) within a set of interaction are not significantly different using DMRT at 5\% level of significance.

\subsection{Panicle Weight}

Effect of variety, Nitrogen and their interactions on panicle weight in 2010 and 2011 cropping seasons were presented in Table 6. There was no significant difference observed on panicle weight as influenced by variety in both 2010 and 2011 cropping seasons. This might implies that both local and improved varieties of millet produced comparable weight of their panicles as shown in table 6. Although, SOSAT C-88 recorded higher mean weight than Zango millet. Panicle weight has been significant affected by Nitrogen fertilizer levels applied in both 2010 and 2011 cropping seasons. From Table 6,120 $\mathrm{kgNha}^{-1}$ recorded the highest panicle weight in both cropping seasons. This may be attributed to the application of fertilizer in split doses of two halves. Half of the dose as top dressing at two weeks after sowing and other half at four weeks after sowing as recommended by Onwueme \& Sinha (1991) [27]. The interaction of variety and Nitrogen fertilizer application revealed no significant effect on millet panicle weight. This is in conformity with what was reported by De Parseval et al. (2017) [28], that there is great intra-plant competition for nutrients and moisture as more heads were produced per stand and this intra-plant competition is detrimental to high grain yields.

Table 6. Interactions effect of varieties, and Nitrogen on Panicle weight (kgha-1) in 2010 and 2011 cropping seasons at Usmanu Danfodiyo University Teaching and Research Dry Land Farm, Sokoto

\begin{tabular}{cccc}
\hline Treatments & $\mathbf{2 0 1 0}$ & $\mathbf{2 0 1 1}$ \\
\hline Variety (V) & 5374 & 5293 \\
SOSAT C-88 & 4975 & 4892 \\
Zango Millet & 161.5 & 158.5 \\
SE \pm & $\mathrm{Ns}$ & $\mathrm{Ns}$ \\
\hline Significance & $\mathbf{2 0 1 0}$ & $\mathbf{2 0 1 1}$ \\
\hline Nitrogen (N) kgha $^{-1}$ & $3582^{\mathrm{c}}$ & $3469^{\mathrm{c}}$ \\
\hline 0 & $5195^{\mathrm{b}}$ & $5118^{\mathrm{b}}$ \\
40 & $5718^{\mathrm{ab}}$ & $5661^{\mathrm{ab}}$ \\
120 & $6202^{\mathrm{a}}$ & $6123^{\mathrm{a}}$ \\
SE \pm & 228.4 & 224.1 \\
Significance & $*$ & $*$ \\
\hline Interaction & $\mathrm{Ns}$ & $\mathrm{Ns}$ \\
\hline
\end{tabular}

Means in a column followed by similar letter (s) are not significantly different at $5 \%$ level of significance using Duncan's Multiple Range Test (DMRT) ns= not significant, * = significant at 5\% level.

\subsection{Stover Yield}

Stover yield in 2010 and 2011 cropping seasons had significantly affected by variety as shown in Table 7: However, in comparing their means, the improved variety (SOSAT C- 88) had higher Stover weight (yield) than the local variety (Zango millet). This is not in line with the findings of Raemaekers (2001) [24] who reported that improved varieties, has low Stover weight compared to the land races. Significantly Stover yield in 2010 and 2011 cropping season were recorded as influenced by nitrogen fertilizer application as shown in Table 7. The three levels of nitrogen application were at par in both cropping season in term of Stover yield. The levels were however differed significantly from the control $\left(0 \mathrm{kgha}^{-1}\right)$. This may be attributed to the application of fertilizer in split doses of two halves. Half of the dose as top dressing at two weeks after sowing and other half at four weeks after sowing as recommended by Onwueme \& Sinha (1991) [27]. Higher level of nitrogen fertilizer, $80 \mathrm{kgha}^{-1}$ and $120 \mathrm{kgha}^{-1} \mathrm{produced}$ more Stover yield than $40 \mathrm{kgha}^{-1}$ and $0 \mathrm{kgha}^{-1}$ (the control). This may be attributed to the importance of fertilizer application at appropriate time (split) two weeks after sowing (2 WAS) and four weeks after sowing (4 WAS) for increased fertilizer use efficiency and yield (Stover). There were no significant interaction effect $(\mathrm{P}>0.05)$ among the factors on Stover yield in both cropping season. 
Table 7. Effect of varieties, nitrogen levels on Stover yield (kgha-1) in 2010 and 2011 cropping seasons at Usmanu Danfodiyo University Teaching and Research Dry Land Farm, Sokoto

\begin{tabular}{|c|c|c|}
\hline Treatments & \multirow{2}{*}{2010} & \multirow{2}{*}{2011} \\
\hline Variety (V) & & \\
\hline SOSAT C- 88 & $15871^{\mathrm{a}}$ & $15722^{\mathrm{a}}$ \\
\hline Zango Millet & $13755^{\mathrm{b}}$ & $13634^{\mathrm{b}}$ \\
\hline $\mathrm{SE} \pm$ & 536.52 & 537.27 \\
\hline Significance & $*$ & $*$ \\
\hline Nitrogen $(\mathbf{N})$ kgha $^{-1}$ & 2010 & 2011 \\
\hline 0 & $11061^{\mathrm{b}}$ & $10839^{\mathrm{b}}$ \\
\hline 40 & $15269^{\mathrm{a}}$ & $15172^{\mathrm{a}}$ \\
\hline 80 & $15676^{\mathrm{a}}$ & $15627^{\mathrm{a}}$ \\
\hline 120 & $17246^{a}$ & $17074^{a}$ \\
\hline $\mathrm{SE} \pm$ & 758.75 & 759.82 \\
\hline Significance & $*$ & $*$ \\
\hline Interaction & Ns & Ns \\
\hline
\end{tabular}

Means in a column followed by similar letter (s) are not significantly different at $5 \%$ level of significance using Duncan's Multiple Range Test (DMRT) ns= not significant, $*=$ significant at $5 \%$ level.

\subsection{Grain Yield}

The result indicated there was a significant effect of variety on grain yield from both the 2010 and 2011 cropping seasons. Table 8 shows that SOSAT C- 88 from both trials recorded the higher significant differences compared to the local (Zango millet). This variation in grain yield is in accordance with the report by Raemaekers (2001) [24] that improved varieties have a higher grain yield per unit area than the local varieties. As shown in Table 8, there was a significant effect of nitrogen fertilizer levels on grain yields in both the 2010 and 2011 cropping seasons. Nitrogen application had a significant effect $(\mathrm{P}<0.05)$ on the grain yield of millet in both seasons. Application of $80 \mathrm{kgha}^{-1}$ and that of $120 \mathrm{kgha}^{-1}$ were not significant in 2010 and 2011 cropping seasons. Three levels were statistically different from $40 \mathrm{kgha}^{-1}$ and the control $\left(0 \mathrm{kgha}^{-1}\right)$ in the 2010 and 2011 cropping seasons. The control $0 \mathrm{kgha}^{-1}$ and the $40 \mathrm{kgha}^{-}$ ${ }^{1}$ differed significantly in both seasons. At 0-40 $\mathrm{KgNha}^{-1}$, there was an increase in grain yield, but at $80-120 \mathrm{KgNha}^{-1}$, there was a maximum yield increase. Similar results were reported by Hassan \& Bibinu (2010) [26]. In their studies, application of $90 \mathrm{kgNha}^{-1}$ gave grain yields of $2467 \mathrm{kgha}^{-1}, 2153 \mathrm{kgha}^{-1}$, and $1700 \mathrm{kgha}^{-1}$ for SOSAT C-88, LCIC9702, and Ex-Borno varieties, respectively. The interaction of variety and nitrogen fertilizer application showed no significant effect on grain yield in both experiments.

Table 8. Effect of varieties, nitrogen levels on Grain yield $\left(\mathrm{kgha}^{-1}\right)$ in 2010 and 2011 cropping seasons at Usmanu Danfodiyo University Teaching and Research Dry Land Farm, Sokoto

\begin{tabular}{cccc}
\hline Treatments & & $\mathbf{2 0 1 0}$ & $\mathbf{2 0 1 1}$ \\
\hline Variety $(\mathbf{V})$ & & $2592^{\mathrm{a}}$ \\
\hline SOSAT C-88 & $2687^{\mathrm{a}}$ & $2251^{\mathrm{b}}$ \\
Zango Millet & $2332^{\mathrm{b}}$ & 86.67 \\
SE \pm & 88.36 & $*$ \\
Significance & $*$ & $\mathbf{2 0 1 1}$ \\
\hline Nitrogen $(\mathbf{N}) \mathbf{k g h a}^{-1}$ & $\mathbf{2 0 1 0}$ & $1689^{\mathrm{c}}$ \\
\hline 0 & $1775^{\mathrm{c}}$ & $2421^{\mathrm{b}}$ \\
40 & $2503^{\mathrm{b}}$ & $2798^{\mathrm{a}}$ \\
120 & $2897^{\mathrm{a}}$ & $2779^{\mathrm{a}}$ \\
SE \pm & $2865^{\mathrm{a}}$ & 122.57 \\
Significance & 124.96 & $*$ \\
\hline Interaction & $*$ & Ns \\
\hline
\end{tabular}

Means in a column followed by similar letter (s) are not significantly different at $5 \%$ level of significance using Duncan's Multiple Range Test (DMRT) ns= not significant, * = significant at $5 \%$ level. 


\section{Conclusion}

The millet varieties did not vary in tiller production and height variation occurred in panicle length, panicle weight, stover yield, and grain yield. There were significant effects of fertilizer rates on all the millet attributes. The improved millet variety, coupled with a higher dose of fertilizer, gave better millet performance in all the yield attributes. As a result, improved millet varieties and NPK fertilizer application at $120 \mathrm{KgNha}^{-1}$ were suggested.

\section{Declarations}

\subsection{Author Contributions}

Conceptualization, S.I. and A.U.G.; methodology, Y.A.; software, S.I., A.U.G., T.S.B., and T.M.; formal analysis Y.A.; investigation T.M.; resources, S.I.; data curation, A.U.G.; writing - original draft preparation, S.I., A.U.G., and Y.A.; writing - review and editing, T.S.B.; visualization, A.U.G.; supervision, A.U.G. and Y.A. project administration, T.S.B. All authors have read and agreed to the published version of the manuscript

\subsection{Data Availability Statement}

We declared that this trial was conducted in 2010 and 2011 rainy seasons at Usmanu Danfodiyo University, Sokoto Teaching and Research Dry Land Farm, Dundaye located on latitude $13^{\circ} 01^{1} \mathrm{~N}$; longitude $5^{\circ} 15^{1} \mathrm{E}$ and at an altitude of about $350 \mathrm{~m}$ above sea level in the Sudan savanna agro-ecological zone of Nigeria. The results written on this paper is originated from the data took on this trial.

\subsection{Funding}

The authors received no financial support for the research, authorship, and/or publication of this article.

\subsection{Institutional Review Board Statement}

Not applicable.

\subsection{Informed Consent Statement}

Not applicable.

\subsection{Declaration of Competing Interest}

The authors declare that there is no conflict of interests regarding the publication of this manuscript. In addition, the ethical issues, including plagiarism, informed consent, misconduct, data fabrication and/or falsification, double publication and/or submission, and redundancies have been completely observed by the authors.

\section{References}

[1] International Crop Research Institute for Semi-Arid Tropics (ICRISAT), (2006): Pearl millet. Available online: http://www.Icrisat.org. (accessed on July 2020).

[2] Sanjana Reddy, P. (2017). Pearl Millet, Pennisetum glaucum (L.) R. Br. Millets and Sorghum, John Wiley \& Sons, 49-86. doi:10.1002/9781119130765.ch2.

[3] Iwuala, E. N., Odjegba, V. J., Sharma, V., \& Alam, A. (2020). Highlights of strategies adapted by two Pennisetum glaucum (L.) R. Br. Races in a simulated drought stress experiment. Plant Gene, 23, 100238. doi:10.1016/j.plgene.2020.100238.

[4] Anonymous, (1975): Notes on the experimental cropping system improvement programme in: cropping scheme meeting institute of agricultural research, Samaru, ABU Zaria, Nigeria.

[5] Railey, K., (2006): Whole Grains: Millet (Gramineae/Poaceae) Available online: http://Chetday.com (accessed on July 2020).

[6] Kumar, K.A. (1989). Pearl millet: current status and future potentials outlook on Agriculture, 18(2), 2-8.

[7] Singh, C., Singh, P. and Singh, R. (2009): Pearl millet, Modem techniques of raising field crops, 131-146.

[8] Gruhn, P. Golleti, F. and Yudelman, M. (2000): Food, Agriculture and Environment Discussion Paper 32. Integrated Nutrient Management. Soil Fertility and Sustainable Agriculture: Current Issues and Future Challenges. International Food Policy Research Institute, Washington, USA.

[9] Singh, L. and Thakare (1986): Yield Response and Nitrogen Uptake of Pearl millet (Pennisetum Americanum (L) Leeke) Cultivare to Nitrogen Application in the Savanna Region of Nigeria. Fertilizer Research, 10, 113-118.

[10] Okafor, M.O. (1999). Effect of liming and manuring ultisol soils with locally available material for aluminum reduction and maize grain production in Ishiagu, Southeastern Nigeria. In: Babalola, O. U. Omoti, and A.E. Isenmila (Ed.). Management of the soil resources of Nigeria for sustainable agricultural production in the 21st century. Proceedings of the 21st Annual conference of the Soil Science Society of Nigeria, held at Benin, Edo State, Nigeria. 21st - 25th Nov. 1999. pp. 179 - 184. 
[11] Usman, A., O.A. Osunde, A. Bala and M.I.S. Ezenwa (2007): Carbon and Nitrogen Mineralization of Some Selected Species. In: Oyivbisere E.O., B.A. Raji, A.A. Yusuf, O. Ogunwole, L. ALiyu and S.O. Ojeniyi (eds.). Soil and Water Management for Poverty Alleviation and Sustainable Environment. Proceedings of 31st Annual Conference of the Soil Science Society of Nigeria, held at Ahmadu Bello University, Samaru Zaria, Kaduna State, Nigeria. Nov. 13th - 17th 2006.

[12] Adeboye, M.K.A, E.N.O. Iwuafor and J. Agbenin (2006): Rotation effect of grain and herbaceous legume on maize yield and Chemical Properties of an Alfiso in the Northern Guinea Savanna. Nigerian Journal of Soil Science Research. 6: pp. 22-31.

[13] Sobulo, R.A. and O.A. Osiname (1985): Fertilizer use in the tropics, Nigerian experience. In: Sobulo R.A., and E.J. Udo (eds). Soil fertility and degradation in the Tropics. pp. 231.

[14] Roe, A. (2006): “Growing Millet. Management Package for dry-land” Available online: http://www.wantfa.com. (accessed on March 2020).

[15] Ustimenko-Bakumovsky, G.V. (1983); Plant growing in the Tropics and Sub Tropics. Translated from Russian by Vicktorova, M.K. Victorova, M.K., (1983). Plants Growing in the Tropics and sub-tropics. MIR, Publisher Moscow 397 pp.

[16] FAO and ICRISAT (1996): the world sorghum and Economic: Facts Trends and outlook. Food and Agricultural Organization of United Nations Rome, Italy and International Crop Research Institute for the Semi-arid Tropics. Pantancheru 502, 324 Andbra Pradesh, India, pp. 68.

[17] Kowal, J.M. and D.T. Knabe (1972). An Agro-ecological Atlas of the Northern Nigeria. Ahmadu Bello University Press, Zaria, Nigeria.

[18] NIMET, (2011). Nigeria Meteorological Agency. Weather report for 2010 and 2011 rainy seasons. Abuja, Nigeria.

[19] Noma, S.S. and M. Yakubu (2002). Properties and Classification of Soils of the main Campus of Usmanu Danfodiyo University, Sokoto. Nigeria. Journal of Agriculture and Environment 3(1), 155-156.

[20] SAS (2003): Statistical Analysis System. SAS. Software SAS Institute, North Carolina, United States.

[21] Gomez, K.A and A.A. Gomez (1984) I: Statistical procedure for Agricultural Research. John Wiley and Sons Limited, New York, United States

[22] Egharevba, P.N.S.M. Abed and D.A. Labe (1984): Effect of row spacing on some agronomic characters and yield of pearl millet (Pennisetum typhoides). (S and H) AGRIS, 29(3), 193-202.

[23] Pandey, S.N and B.K. Sinha (2010): Plant physiology. (4th Edition). Vikas Publishing House, New Delhi, India.

[24] Raemaekers, R.H (2001): Crop Production in Tropical Africa. Royal Library Albert Brussels, Brussels, Belgium.

[25] Jennis. (2006): Millet use in West Africa. Pearl Millet and Sorghum. The Cereals of Subsistence. Available online http://www.cee.mtu.edu.pp (accessed on April 2020).

[26] Hassan, A.M and A.T. S. Bibinu (2010): Effect of Nitrogen on the Growth and Yield of Millet in North-Eastern Nigeria, Maiduguri. Continental journal of Agronomy 4:10-14.

[27] Onwueme, I.C., and T.D. Sinha (1991). Field Crop Production in Tropical Africa: Principles and Practices. TCA publication, Amsterdam, Netherlands.

[28] De Parseval, H., Barot, S., Gignoux, J., Lata, J. C., \& Raynaud, X. (2017). Modelling facilitation or competition within a root system: importance of the overlap of root depletion and accumulation zones. Plant and soil, 419(1), 97-111. doi: 10.1007/s11104-017-3321-y. 